Article

\title{
Facile Preparation of Rod-like MnO Nanomixtures via Hydrothermal Approach and Highly Efficient Removal of Methylene Blue for Wastewater Treatment
}

\author{
Yuelong $X u^{1,2,3,4}$, Bin Ren ${ }^{3,4}$, Ran Wang ${ }^{2}$, Lihui Zhang ${ }^{3,4}$, Tifeng Jiao $1,2, * \mathbb{D}$ \\ and Zhenfa Liu $3,4, *$ (D) \\ 1 State Key Laboratory of Metastable Materials Science and Technology, Yanshan University, \\ Qinhuangdao 066004, China; xudalong.cool@163.com \\ 2 Hebei Key Laboratory of Applied Chemistry, School of Environmental and Chemical Engineering, \\ Yanshan University, Qinhuangdao 066004, China; wr1422520780@163.com \\ 3 Institute of Energy Resources, Hebei Academy of Sciences, Shijiazhuang 050081, China; \\ RENBINTS@126.com (B.R.); zlhkxy@126.com (L.Z.) \\ 4 Hebei Engineering Research Center for Water Saving in Industry, Shijiazhuang 050081, China \\ * Correspondence: tfjiao@ysu.edu.cn (T.J.); lzf63@sohu.com (Z.L.); Tel.: +86-335-8056854 (T.J.)
}

Received: 12 December 2018; Accepted: 13 December 2018; Published: 22 December 2018

\begin{abstract}
In the present study, nanoscale rod-shaped manganese oxide $(\mathrm{MnO})$ mixtures were successfully prepared from graphitic carbon nitride $\left(\mathrm{C}_{3} \mathrm{~N}_{4}\right)$ and potassium permanganate $\left(\mathrm{KMnO}_{4}\right)$ through a hydrothermal method. The as-prepared $\mathrm{MnO}$ nanomixtures exhibited high activity in the adsorption and degradation of methylene blue (MB). The as-synthesized products were characterized by scanning electron microscopy (SEM), transmission electron microscopy (TEM), surface area analysis, X-ray diffraction (XRD), and X-ray photoelectron spectroscopy (XPS). Furthermore, the effects of the dose of $\mathrm{MnO}$ nanomixtures, $\mathrm{pH}$ of the solution, initial concentration of $\mathrm{MB}$, and the temperature of $\mathrm{MB}$ removal in dye adsorption and degradation experiments was investigated. The degradation mechanism of $\mathrm{MB}$ upon treatment with $\mathrm{MnO}$ nanomixtures and $\mathrm{H}_{2} \mathrm{O}_{2}$ was studied and discussed. The results showed that a maximum adsorption capacity of $154 \mathrm{mg} \mathrm{g}^{-1}$ was obtained for a $60 \mathrm{mg} \mathrm{L}^{-1} \mathrm{MB}$ solution at $\mathrm{pH} 9.0$ and $25^{\circ} \mathrm{C}$, and the highest $\mathrm{MB}$ degradation ratio reached $99.8 \%$ under the following optimum conditions: $50 \mathrm{~mL}$ of $\mathrm{MB}$ solution $\left(20 \mathrm{mg} \mathrm{L}^{-1}\right)$ at room temperature and $\mathrm{pH} \approx 8.0$ with $7 \mathrm{mg}$ of $\mathrm{C}, \mathrm{N}$-doped $\mathrm{MnO}$ and $0.5 \mathrm{~mL}$ of $\mathrm{H}_{2} \mathrm{O}_{2}$.
\end{abstract}

Keywords: hydrothermal method; manganese oxide; adsorption; degradation; nanomixtures

\section{Introduction}

Water pollution is currently among the major environmental challenges and has attracted increasing research attention. The wide use of dyes has resulted in organic pollution in water, and dyes are considered a severe threat to ecosystems [1-6]. As untreated dyes are very active and stable, adsorption followed by oxidative degradation has emerged as a practical and effective technique to accelerate the treatment of dye effluent pollution. Thus, the following technological systems have been developed for the removal of dyes from water: physical adsorption [7], biodegradation [8,9] and chemical reaction and adsorption [10]. In recent years, photocatalytic decomposition [11-13] and chemical oxidation reduction have become highly efficient techniques for the degradation of methylene blue (MB) in water.

Over the last decades, nanomixtures, mostly nanorods/nanotubes-like structured, have been widely used for contaminant adsorption/removal [14-17]. Cavallaro et al. [15] investigated comprehensively the effect of anionic surfactants (sodium dodecanoate and sodium dodecylsulfate) 
on pristine halloysite nanotubes (HNT), which was beneficial for the solubilization and delivery of hydrophobic compounds from such hybrid materials. Recently, the oxidation degradation of dyes in water using environmentally benign oxidants has attracted considerable attention [18-21]. On this basis, some nontoxic and low-cost metal oxides have been widely used as catalysts for the oxidation of organic compounds [22-25]. Huang et al. [26] reported the application of Prussian blue (PB)-modified $\gamma-\mathrm{Fe}_{2} \mathrm{O}_{3}$ magnetic nanoparticles (PBMNPs) in the degradation of MB. The PBMNPs were used as peroxidase-like catalysts with $\mathrm{H}_{2} \mathrm{O}_{2}$ as the oxidant to completely degrade $\mathrm{MB}$. The optimal conditions were as follows: $\mathrm{pH}$ range of 3 to 10, degradation temperature of $25^{\circ} \mathrm{C}$ and degradation time of $120 \mathrm{~min}$. However, the preparation process for the PBMNPs was very complicated and involved the use of toxic chemicals. Wolski et al. [27] investigated the effects of $\mathrm{ZnO}, \mathrm{Nb}_{2} \mathrm{O}_{5}$ and $\mathrm{ZnNb}_{2} \mathrm{O}_{6}$ on the degradation of dyes, and $\mathrm{MB}$ could be completely degraded under optimal conditions. Nevertheless, the as-reported metal oxides $\left(\mathrm{Nb}_{2} \mathrm{O}_{5}\right.$ and $\left.\mathrm{ZnNb}_{2} \mathrm{O}_{6}\right)$ were highly toxic and expensive.

In recent years, the synergistic application of metal oxides and $\mathrm{H}_{2} \mathrm{O}_{2}$ as peroxidase-like catalysts and an oxidant, respectively, in the degradation of dyes has been reported. Metal oxides can catalyze the generation of active oxygen (such as hydroxyl radicals $(\mathrm{HO})^{\bullet}$ ), peroxides $\left(\mathrm{HO}_{2}{ }^{-}\right)$and superoxide anions $\left(\mathrm{HO}_{2}{ }^{\bullet}\right)$ ) upon $\mathrm{H}_{2} \mathrm{O}_{2}$ treatment, and this active oxygen can catalyze the degradation of dyes in water [28]. Saha et al. reported a novel method to prepare nanodimensional copper ferrite which exhibited high activity in the degradation of dyes in water with $\mathrm{H}_{2} \mathrm{O}_{2}$ as an oxidant [29]. The researchers used ethylenediaminetetraacetic acid and citric acid as the complexing agent and the fuel, respectively, in a modified complexometric method to prepare $\mathrm{CuFe}_{2} \mathrm{O}_{4}$, which had the capability to degrade $96 \%$ of the total MB. Because of its size-, structure- and morphology-dependent characteristics, and the variety of unique physical, chemical and functional properties, hausmannite $(\mathrm{MnO})$ has been widely investigated in the fields of materials science, chemistry and physics. Zhang et al. prepared MnO nanocrystals of various sizes and shapes by soft-template self-assembly and studied the synthetic conditions and degradation mechanism of $\mathrm{MB}$ with $\mathrm{H}_{2} \mathrm{O}_{2}$ treatment [30]. In their report, cetyltrimethylammonium bromide (CTAB), polyvinyl pyrrolidine (PVP) and P123 were used as structure-directing agents; manganese sulfate was used as the source of manganese; and the size and shape of $\mathrm{MnO}$ could be controlled by varying the growth time, reaction temperature, surfactant, and manganese source. The as-prepared $\mathrm{MnO}$ showed a very high capacity for (above 99.7\%) MB degradation.

Recently, Because of its excellent chemical and thermal stabilities and nontoxicity, graphitic carbon nitride $\left(\mathrm{g}-\mathrm{C}_{3} \mathrm{~N}_{4}\right)$ [31-35], a novel 2D material, which was prepared through simple and green pyrolysis of melamine, has been used in many applications, such as energy conversion, biomedical applications and hydrogen production. According to the literature, $\mathrm{g}-\mathrm{C}_{3} \mathrm{~N}_{4}$ can absorb aromatic pollutants via the conjugated $\pi$ region, which makes $g-C_{3} N_{4}$ a potential effective adsorbent. In this paper, the preparation of MnO Nanomixtures through a hydrothermal method with $\mathrm{C}_{3} \mathrm{~N}_{4}$ as the source of carbon and nitrogen and potassium permanganate $\left(\mathrm{KMnO}_{4}\right)$ as the source of manganese was investigated. The effects of the hydrothermal reaction time, molar ratio of $\mathrm{C}_{3} \mathrm{~N}_{4}$ to $\mathrm{KMnO}_{4}$, and hydrothermal temperature on the adsorption capacity for $\mathrm{MB}$ were studied. In addition, the adsorption and degradation properties of the as-prepared product were systematically studied, and thermodynamic and kinetic analyses of the adsorption-degradation process were performed through experiments.

\section{Materials and Methods}

\subsection{Materials}

All reagents were purchased from Shanghai Aladdin Bio-Chem Technology Co., Ltd, Shanghai, China. All reagents were of analytical reagent (AR) grade and were used as received without further treatment. 


\subsection{Synthesis of $C_{3} N_{4}$}

$\mathrm{C}_{3} \mathrm{~N}_{4}$ was prepared by heating melamine $(10 \mathrm{~g})$ at $650{ }^{\circ} \mathrm{C}$ for $4 \mathrm{~h}$ in an air atmosphere. After the heat treatment, a light yellow solid was obtained.

\subsection{Synthesis of $\mathrm{MnO}$ Nanomixtures}

$\mathrm{MnO}$ nanomixtures were prepared via a hydrothermal method with $\mathrm{C}_{3} \mathrm{~N}_{4}$ as the source of carbon and nitrogen and potassium permanganate $\left(\mathrm{KMnO}_{4}\right)$ as the source of manganese. Typically, certain amounts of $\mathrm{C}_{3} \mathrm{~N}_{4}$ power and $\mathrm{KMnO}_{4}$ were put into a $100 \mathrm{~mL}$ hydrothermal reactor. The molar ratios of $\mathrm{C}_{3} \mathrm{~N}_{4}$ to $\mathrm{KMnO}_{4}$ were 2.0, 4.0 and 6.0, and the mass concentration of the reactants $\left(\mathrm{C}_{3} \mathrm{~N}_{4}+\mathrm{KMnO}_{4}\right)$ in the solution was $12 \%$. The hydrothermal temperature was set as $180^{\circ} \mathrm{C}$, and the hydrothermal reaction times were $24 \mathrm{~h}$ and $30 \mathrm{~h}$. The as-prepared $\mathrm{MnO}$ nanomixtures with a hydrothermal reaction time of $30 \mathrm{~h}$ were denoted $\mathrm{MnO}-\mathrm{X}(\mathrm{X}=2,4$, and 6), where $\mathrm{X}$ represents the reactants molar ratio of $\mathrm{C}_{3} \mathrm{~N}_{4}$ to $\mathrm{KMnO}_{4}$. The sample prepared with a molar ratio of 4.0 and a hydrothermal reaction time of $24 \mathrm{~h}$ was denoted as MnO-24.

\subsection{MB Adsorption and Degradation Experiments}

In the adsorption experiments, $50 \mathrm{~mL}$ of $10-60 \mathrm{mg} \mathrm{L}^{-1} \mathrm{MB}$ aqueous solutions containing $5 \mathrm{mg}$ of the $\mathrm{MnO}$ nanomixtures adsorbent were stirred at different temperatures $(293.15-333.15 \mathrm{~K})$ and different $\mathrm{pH}$ values (3.0-11.0) for MB adsorption. After an adsorption time of 20-300 min, the adsorbent solution was centrifuged, and the supernatant was examined by a UV-Vis spectrophotometer (TU-1900, Beijing Persee Instruments Co. Ltd., Beijing, China) to determine the MB concentration. The maximum wavelength of $\mathrm{MB}$ absorption was observed at $\lambda=665 \mathrm{~nm}$.

The reusability of the $\mathrm{MnO}$ nanomixtures adsorbent was also investigated via 10 consecutive adsorption/desorption cycles. Briefly, the $\mathrm{MnO}$ nanomixtures with $\mathrm{MB}$ adsorbed were stirred in $50 \mathrm{~mL}$ of $\mathrm{HCl}$ solution $(0.1 \mathrm{M})$ for $120 \mathrm{~min}$, and then, the adsorbent was washed three times with distilled water. The adsorbed $\mathrm{MB}$ was desorbed from the $\mathrm{MnO}$ nanomixtures adsorbent, and the recovered $\mathrm{MnO}$ nanomixtures adsorbent was used to adsorb MB in another cycle. This cycle of adsorption and desorption was performed 10 times. The amount of $\mathrm{MB}$ adsorbed $\left(\mathrm{q}_{\mathrm{t}}\right)$ was calculated according to Equation (1):

$$
\mathrm{q}_{\mathrm{t}}=\frac{\left(\mathrm{C}_{0}-\mathrm{C}_{\mathrm{t}}\right) \mathrm{V}}{\mathrm{W}}
$$

where $\mathrm{C}_{0}$ is the initial concentration of $\mathrm{MB}\left(\mathrm{mg} \mathrm{L}^{-1}\right), \mathrm{C}_{\mathrm{t}}$ is the concentration of $\mathrm{MB}$ at contact time $\mathrm{t}$ $\left(\mathrm{mg} \mathrm{L}^{-1}\right), \mathrm{V}$ is the volume of the MB solution $(\mathrm{L})$, and $\mathrm{W}$ is the weight of the adsorbent $(\mathrm{g})$.

The MB degradation process was carried out in a $100 \mathrm{~mL}$ beaker containing $50 \mathrm{~mL}$ of a $\mathrm{MB}$ dye solution ( $20 \mathrm{mg} \mathrm{L}^{-1}$ or $40 \mathrm{mg} \mathrm{L}^{-1}$ ), $0.5 \mathrm{~mL}$ of $30 \% \mathrm{H}_{2} \mathrm{O}_{2}$, and $7 \mathrm{mg}$ of $\mathrm{MnO}$ nanomixtures. The degradation time was varied from $0 \mathrm{~h}$ to $24 \mathrm{~h}$, and the $\mathrm{MB}$ concentration was monitored by a UV-Vis spectrophotometer.

\subsection{Characterization}

$\mathrm{MnO}$ nanomixtures were characterized by X-ray diffraction (XRD, SMART LAB, Rigaku, Akishima, Japan) with CuKa radiation $(\lambda=1.54 \AA$ ), scanning electron microscopy (SEM, Field Emission Gun FEI QUANTA FEG 250, FEI Corporate, Hillsboro, OR, USA), transmission electron microscopy (TEM, HT7700, High-Technologies Corp., Ibaraki, Japan) and X-ray photoelectron spectroscopy (XPS, ESCALAB 250Xi XPS, Thermo Fisher Scientific, San Jose, CA, USA). The Brunauer-Emmett-Teller (BET) method was utilized to calculate the specific surface areas (ASAP2420 surface area analyzer, Micromeritics, Norcross, GA, USA). The pore volume and pore size were calculated from the adsorption-desorption isotherms using the Barrett-Joyner-Halenda (BJH) model. The total pore volume $\left(\mathrm{V}_{\text {total }}\right)$ was estimated from the amount adsorbed at a relative pressure $\left(\mathrm{P} / \mathrm{P}_{0}\right)$ of 0.998 . 


\subsection{Kinetic, Adsorption and Degradation Isotherm Models}

The kinetics of the adsorption process were studied through kinetic models in our work. The pseudo-first-order kinetic model (2) and pseudo-second-order kinetic model (3) were adopted to fit the experimental data.

$$
\begin{gathered}
\ln \left(\mathrm{q}_{\mathrm{e}}-\mathrm{q}_{\mathrm{t}}\right)=\ln \mathrm{q}_{\mathrm{e}}-\mathrm{k}_{1} \mathrm{t} \\
\frac{\mathrm{t}}{\mathrm{q}_{\mathrm{t}}}=\frac{1}{\mathrm{k}_{2} \mathrm{q}_{\mathrm{e}}^{2}}+\frac{\mathrm{t}}{\mathrm{q}_{\mathrm{e}}}
\end{gathered}
$$

In these equations, $\mathrm{q}_{\mathrm{e}}$ represents the equilibrium absorption capacity $\left(\mathrm{mg} \mathrm{g}^{-1}\right)$, $\mathrm{q}_{\mathrm{t}}$ represents the absorption amount $\left(\mathrm{mg} \mathrm{g}^{-1}\right)$ at an absorption time of $\mathrm{t}(\mathrm{min})$, and $\mathrm{k}_{1}$ and $\mathrm{k}_{2}$ are the pseudo-first-order rate constant $\left(\mathrm{min}^{-1}\right)$ and the pseudo-second-order rate constant $\left(\mathrm{g} \mathrm{mg}^{-1} \cdot \mathrm{min}^{-1}\right)$, respectively.

The Langmuir isotherm model (4) was adopted to investigate the surface properties, adsorbate affinity and adsorption capacity of $\mathrm{MnO}$ nanomixtures.

$$
\frac{C_{e}}{q_{e}}=\frac{1}{q_{m} b}+\frac{C_{e}}{q_{m}}
$$

In this equation, $\mathrm{q}_{\mathrm{e}}\left(\mathrm{mg} \mathrm{g}^{-1}\right)$ is the equilibrium adsorption capacity, $\mathrm{q}_{\mathrm{m}}\left(\mathrm{mg} \mathrm{g}^{-1}\right)$ is the maximum adsorption capacity (corresponding to complete monolayer coverage), $\mathrm{C}_{\mathrm{e}}\left(\mathrm{mg} \mathrm{L}^{-1}\right)$ is the adsorbate concentration at the adsorption equilibrium, and $b\left(\mathrm{~L} \mathrm{mg}^{-1}\right)$ is a constant. The kinetics of the degradation process was also investigated via the pseudo-first-order kinetic model (2).

\subsection{Thermodynamic Evaluation of the Adsorption Process}

The thermodynamics of the adsorption process were obtained from Equations (5)-(7).

$$
\begin{gathered}
\mathrm{K}_{\mathrm{c}}=\frac{\mathrm{q}_{\mathrm{e}}}{\mathrm{C}_{\mathrm{e}}} \\
\Delta \mathrm{G}^{0}=-\mathrm{RT} \ln \mathrm{K}_{\mathrm{c}} \\
\ln \mathrm{K}_{\mathrm{c}}=\frac{\Delta \mathrm{S}^{0}}{\mathrm{R}}-\frac{\Delta \mathrm{H}^{0}}{\mathrm{RT}}
\end{gathered}
$$

In these equations, $\Delta \mathrm{G}^{0}$ is the standard Gibbs free energy change, $\Delta \mathrm{H}^{0}$ is the standard enthalpy change, $\Delta S^{0}$ is the standard entropy change, $\mathrm{q}_{\mathrm{e}}$ is the equilibrium adsorption capacity, $\mathrm{C}_{\mathrm{e}}\left(\mathrm{mg} \mathrm{L}^{-1}\right)$ is the adsorbate concentration at the adsorption equilibrium, $\mathrm{Kc}$ is the distribution coefficient, $\mathrm{R}$ is the molar gas constant $\left(8.314 \mathrm{~J} \mathrm{~mol}^{-1} \mathrm{~K}^{-1}\right)$, and $\mathrm{T}$ is the adsorption temperature $(\mathrm{K})$.

\section{Results and Discussion}

The XRD patterns of the as-prepared MnO nanomixtures samples are shown in Figure 1. As presented in Figure 1, the peaks of (111), (200), (220), (311) and (222) were attributed to MnO [36], which indicated that $\mathrm{MnO}$ nanomixtures were successfully prepared via a novel hydrothermal self-assembly method. We also investigated the effect of the hydrothermal reaction time on the formation of $\mathrm{MnO}$ nanomixtures. We found that other manganese oxides were produced when the hydrothermal reaction time was less than $30 \mathrm{~h}$. In the experiment, manganese oxide was the only product when the hydrothermal reaction time exceeded $30 \mathrm{~h}$.

The nitrogen adsorption-desorption isotherms are shown in Figure $2 \mathrm{a}$, and the pore size distribution curves are shown in Figure 2b. As seen in Figure 2a, all the curves corresponded to type-IV isotherms, and hysteresis loops could be clearly observed, illustrating the presence of a pore structure. The high $\mathrm{P} / \mathrm{P}_{0}$ of the hysteresis loops indicated a large pore size distribution, which was in accordance with the pore size distribution curves. As shown in Figure 2b, the as-prepared $\mathrm{MnO}$ nanomixtures samples exhibited a micro-mesoporous structure. The surface properties, consisting of 
the specific surface area $\left(S_{\mathrm{BET}}\right)$, micropore surface area $\left(\mathrm{S}_{\text {micro }}\right)$, average pore diameter $\left(\mathrm{D}_{\text {average }}\right)$ and total pore volume $\left(\mathrm{V}_{\text {total }}\right)$, are listed in Table 1 . MnO-4 showed the largest surface area and total pore volume, which were beneficial for adsorption. As presented in Table 1, the molar ratio of $\mathrm{C}_{3} \mathrm{~N}_{4}$ to $\mathrm{KMnO}_{4}$ and the hydrothermal reaction time exerted obvious effects on the textural properties, in which shorter hydrothermal reaction times and higher or lower molar ratios affected the hydrothermal self-assembly process.

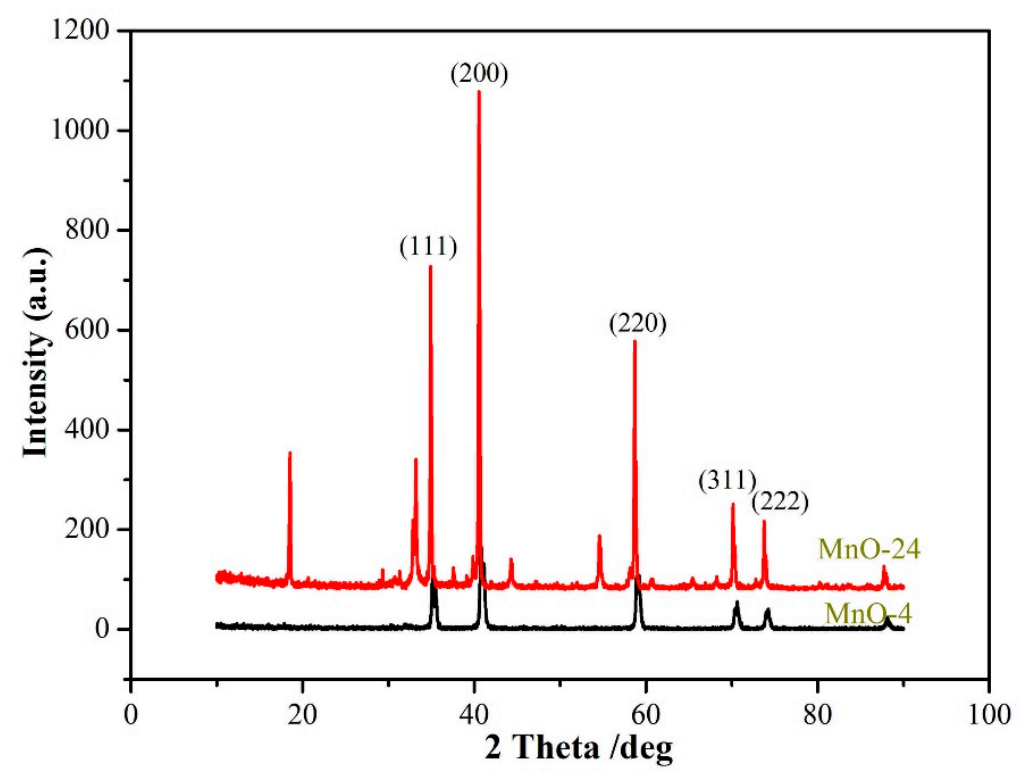

Figure 1. XRD patterns of the as-prepared $\mathrm{MnO}$ nanomixtures samples.
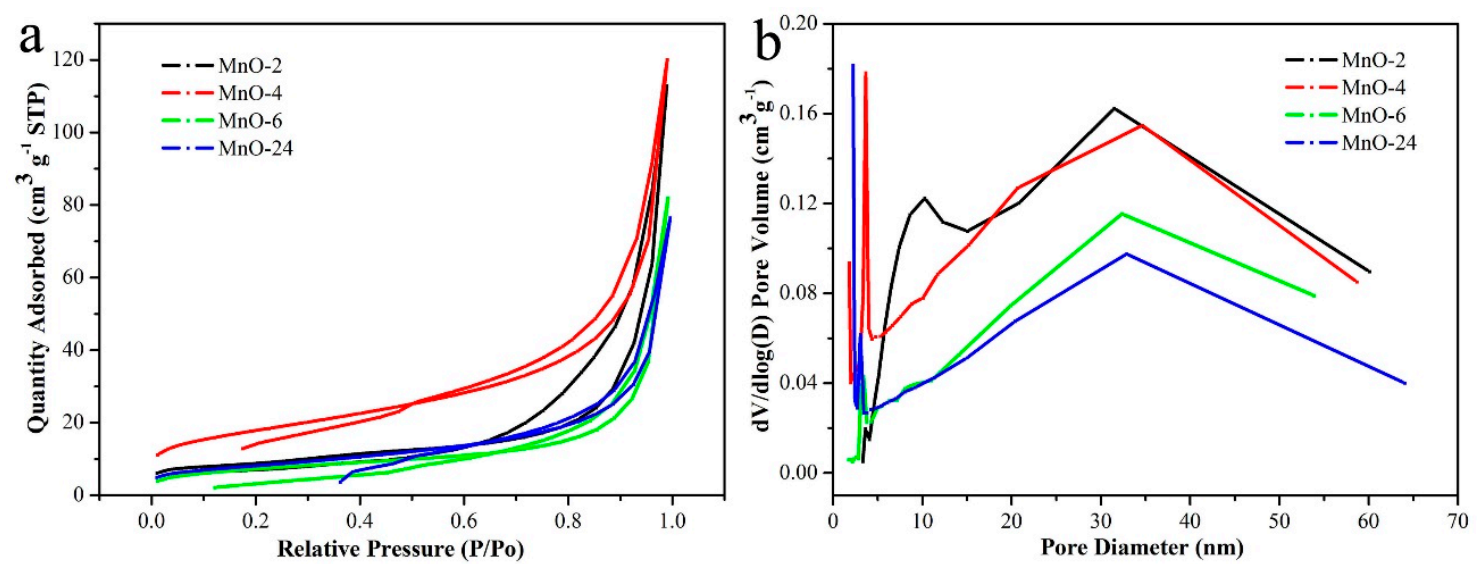

Figure 2. Nitrogen adsorption-desorption isotherms (a) and pore size distributions (b).

Table 1. Surface characterization of different samples.

\begin{tabular}{ccccc}
\hline Entry & $\mathbf{S}_{\text {BET }}\left(\mathbf{m}^{\mathbf{2}} \mathbf{g}\right)$ & $\mathbf{S}_{\text {micro }}\left(\mathbf{m}^{\mathbf{2}} \mathbf{g}\right)$ & Daverage $(\mathbf{n m})$ & $\mathbf{V}_{\text {total }}\left(\mathbf{c m}^{\mathbf{3}} / \mathbf{g}\right)$ \\
\hline $\mathrm{MnO}-2$ & 30.6 & 6.3 & 22.81 & 0.175 \\
$\mathrm{MnO}-4$ & 38.7 & 8.5 & 23.09 & 0.193 \\
$\mathrm{MnO}-6$ & 35.5 & 1.0 & 21.46 & 0.127 \\
$\mathrm{MnO}-24$ & 33.9 & 1.6 & 15.97 & 0.168 \\
\hline
\end{tabular}

SEM images of the as-prepared MnO nanomixtures samples and TEM images of MnO-4 are shown in Figures 3 and 4. The nanoscale rod-shape of C, N-doped MnO can be clearly seen in Figure 3; this product was formed via the polymerization of $\mathrm{C}_{3} \mathrm{~N}_{4}$ and oxidation by $\mathrm{KMnO}_{4}$. As shown in Figure $3 \mathrm{~d}$, the amount of rod-shaped $\mathrm{MnO}$ nanomixtures particles in $\mathrm{MnO}-24$ was less than that in 
the other samples, which was caused by the shorter hydrothermal reaction time. When the molar ratio of $\mathrm{C}_{3} \mathrm{~N}_{4}$ to $\mathrm{KMnO}_{4}$ was more than 4.0, many linked spherical particles were formed, as shown in Figure 3c; there particles formed through the polymerization of excess $\mathrm{C}_{3} \mathrm{~N}_{4}$ in the hydrothermal process. As presented in Figure 4a,b, nanoscale rod-shaped $\mathrm{MnO}$ nanomixtures particles were clearly observed. The lattice fringe spacing was determined from Figure $4 \mathrm{c}$ and was attributed to the presence of manganese.
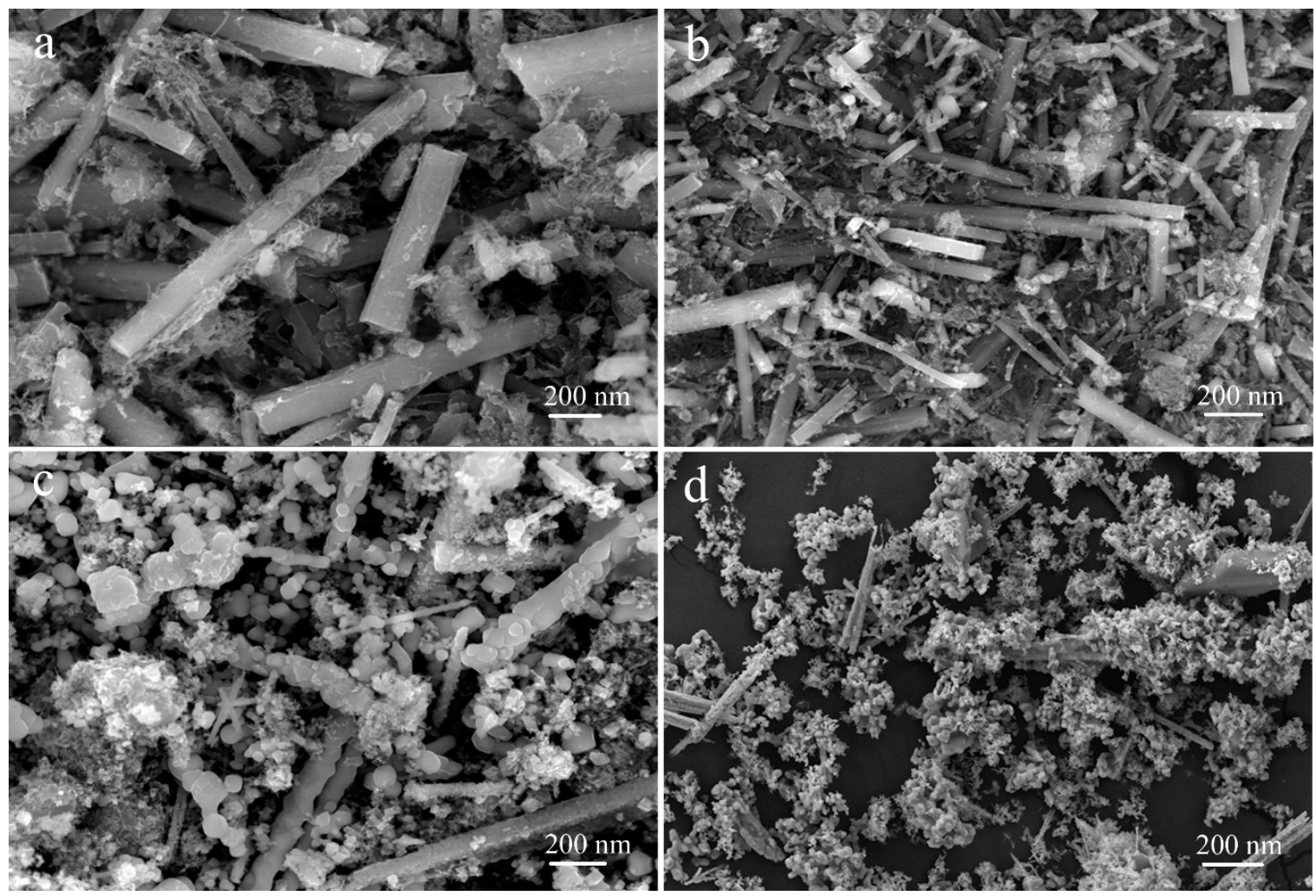

Figure 3. Images of $\mathrm{MnO}-2$ (a), $\mathrm{MnO}-4$ (b), MnO-6 (c) and $\mathrm{MnO}-24$ (d).
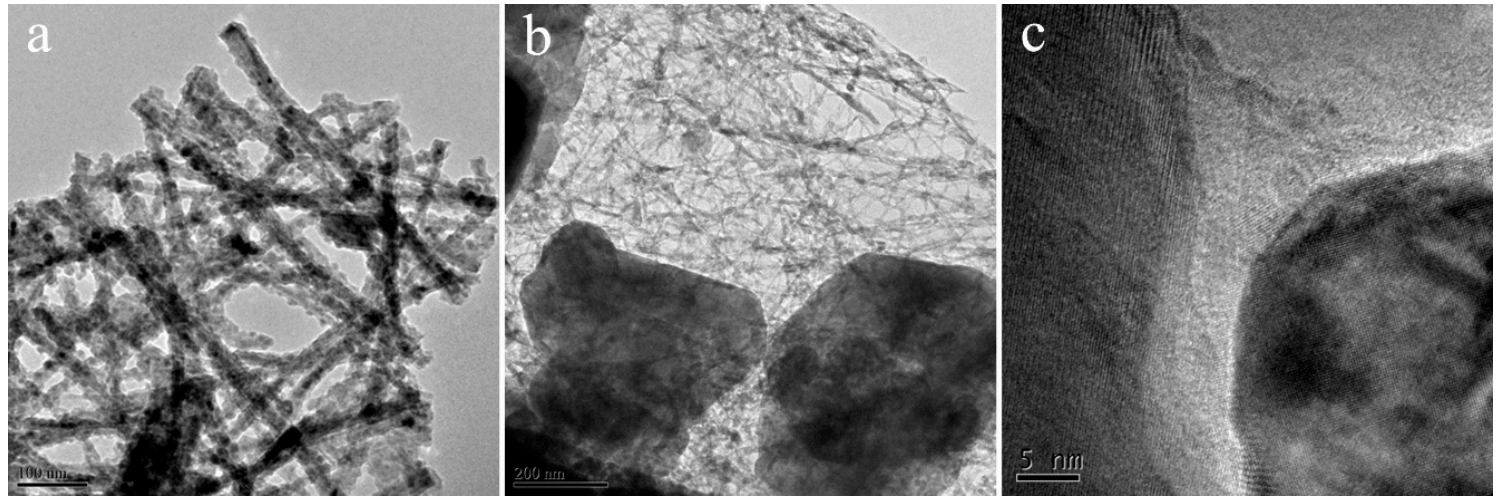

Figure 4. TEM images (a,b) and high resolution image (c) of MnO-4.

XPS was performed to analyze the chemical nature of MnO-4; the results are shown in Figure 5. Figure 5 a reveals the presence of $\mathrm{C}, \mathrm{K}, \mathrm{O}, \mathrm{N}$ and $\mathrm{Mn}$, which corresponded to peaks at $285 \mathrm{eV}, 300 \mathrm{eV}$, $535 \mathrm{eV}, 410 \mathrm{eV}$ and $650 \mathrm{eV}$, respectively. As presented in Figure 5b, five peaks were observed $(284.6 \mathrm{eV}$, $285.3 \mathrm{eV}, 285.9 \mathrm{eV}, 287.4 \mathrm{eV}$ and $289.0 \mathrm{eV}$ ), and these peaks were attributed to $\mathrm{C}-\mathrm{N}-\mathrm{C}, \mathrm{C}-\mathrm{C}, \mathrm{C}-\mathrm{O}, \mathrm{C}=\mathrm{O}$, and $\mathrm{O}-\mathrm{C}=\mathrm{O}$ groups. This result indicated that $\mathrm{C}_{3} \mathrm{~N}_{4}$ was oxidized by $\mathrm{KMnO}_{4}$ in the hydrothermal self-assembly process. The peaks shown in Figure $5 \mathrm{c}$ corresponded to $\mathrm{C}=\mathrm{O}(531.0 \mathrm{eV}), \mathrm{COOH}(532.0 \mathrm{eV})$ and C-O-C (535.0 eV). As shown in Figure 5d, two peaks [7] were observed at $400.3 \mathrm{eV}$ and $398.8 \mathrm{eV}$, 
which were assigned to $\mathrm{N}-\mathrm{C}_{3}$ and $\mathrm{C}-\mathrm{N}-\mathrm{C}$, respectively. The presence of $\mathrm{N}-\mathrm{C}_{3}$ was beneficial for $\mathrm{MB}$ adsorption [37]. The peaks at $641.8 \mathrm{eV}$ and $653.4 \mathrm{eV}$ corresponded to $\mathrm{Mn} 2 \mathrm{p}$, which indicated the presence of manganese.
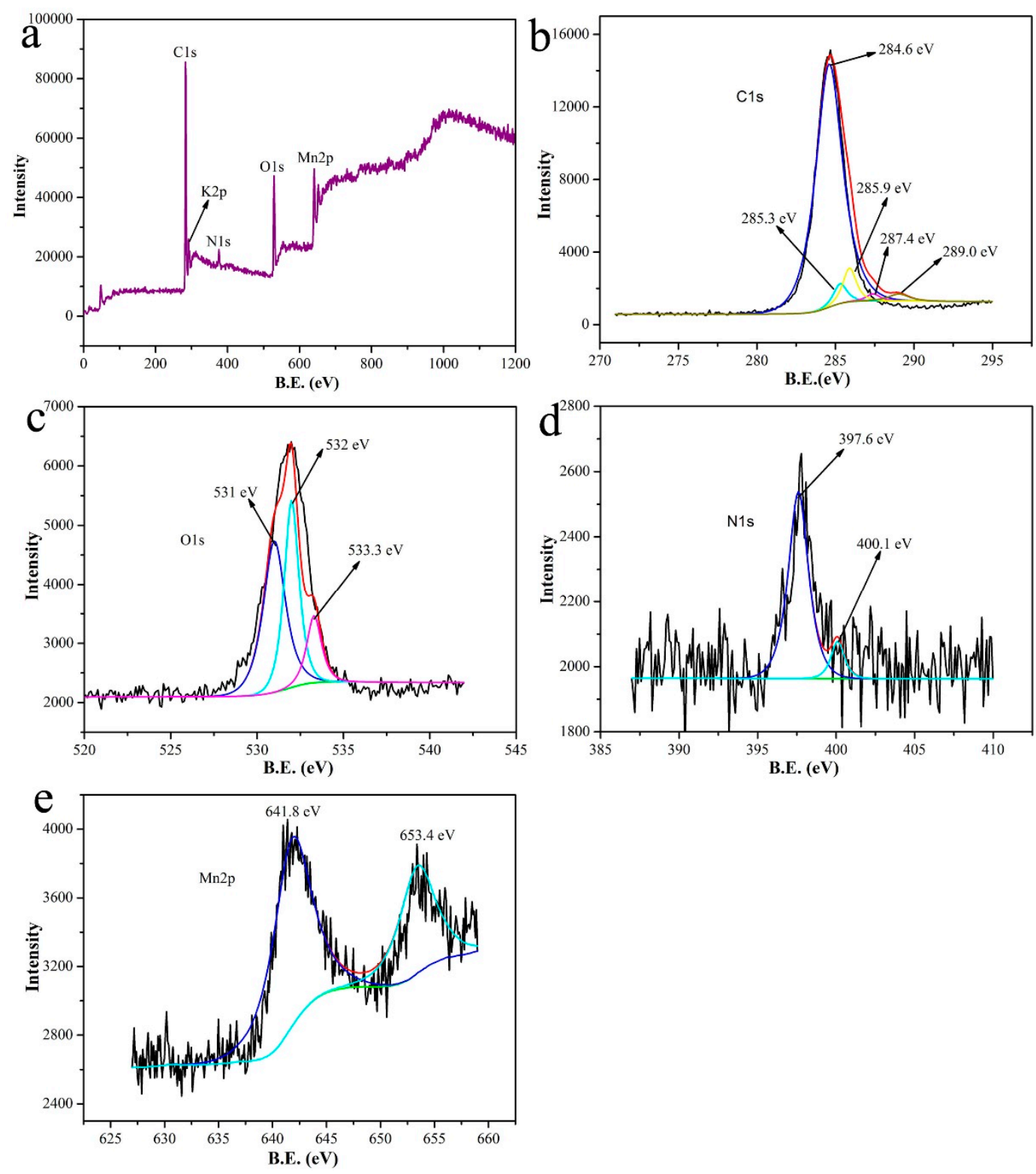

Figure 5. XPS spectra of MnO-4: (a) full-scan spectrum, (b) C 1s spectrum, (c) O 1s spectrum, (d) $\mathrm{N} 1 \mathrm{~s}$ spectrum, and (e) Mn 2p spectrum.

The effect of the different samples on the MB adsorption amount was investigated, and the result is shown in Figure 6. As seen in Figure 6, $\mathrm{MnO}-4$ and $\mathrm{MnO}-6$ exhibited larger adsorption amounts than $\mathrm{MnO}-2$, which was attributed to the higher reactant molar ratio of $\mathrm{C}_{3} \mathrm{~N}_{4}$ to $\mathrm{KMnO}_{4} \cdot \mathrm{C}_{3} \mathrm{~N}_{4}$ introduced a $\pi$-conjugation system in $\mathrm{MnO}$ nanomixtures during the hydrothermal process, which could improve the adsorption capacity. Meanwhile, a moderate dosage of $\mathrm{KMnO}_{4}$ could improve the surface area to increase the adsorption of MB. From the comparison of the adsorption amounts of MnO-4 and MnO-24, the hydrothermal reaction time exerted an effect on the adsorption capacity, in which MnO-4 had a higher adsorption capacity of up to $137 \mathrm{mg} \mathrm{g}^{-1}$ in a $20 \mathrm{mg} \mathrm{L}^{-1} \mathrm{MB}$ solution at $20^{\circ} \mathrm{C}$. The zeta potentials of $\mathrm{MnO}-2, \mathrm{MnO}-4, \mathrm{MnO}-6$ and $\mathrm{MnO}-24$ in water were as follows: $-29.8 \mathrm{mV},-42.3 \mathrm{mV}$, 
$-37.1 \mathrm{mV}$, and $-34.7 \mathrm{mV}$, respectively. $\mathrm{MB}$ is a cationic dye; thus, the lower the zeta potential is, the better the adsorption.

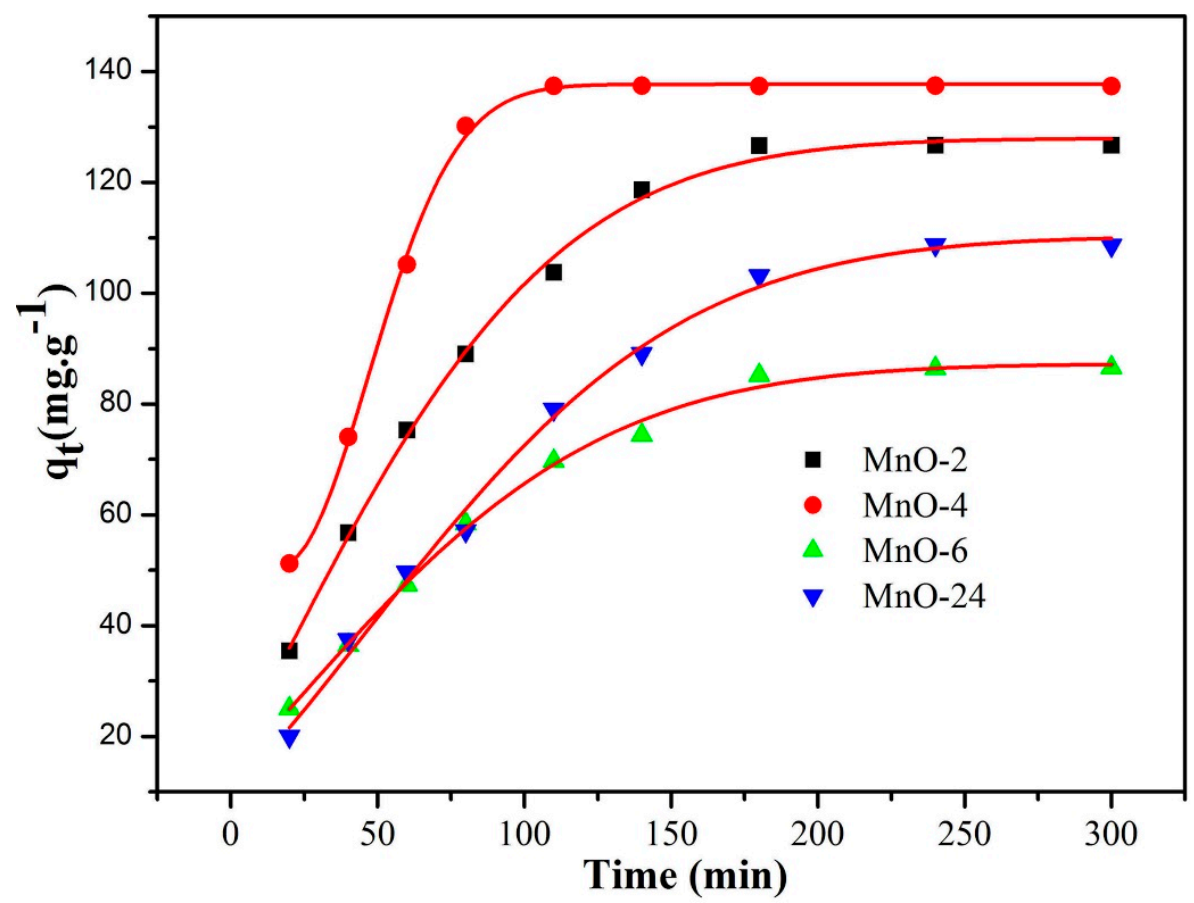

Figure 6. MB adsorption curves of the as-prepared samples.

The effect of the MB concentration on the adsorption capacity is shown in Figure 7a, in which the adsorption capacity was observed to increase with the MB concentration. The higher the MB concentration, the shorter the adsorption equilibrium time was. The MB adsorption efficiency was up to $96 \%$ for an $\mathrm{MB}$ concentration of $10 \mathrm{mg} \mathrm{L}^{-1}$ at $150 \mathrm{~min}$. As seen in Figure $7 \mathrm{~b}$, an equilibrium plateau was reached, which indicated that $\mathrm{MnO}-4$ acted as a monolayer adsorbent in $\mathrm{MB}$ absorption. The Langmuir model was adopted to investigate the adsorption process on the MnO-4 surface, and the results are shown in Figure 7c. The correlation coefficient $\left(R^{2}\right)$ of the fitted curve was 0.996, which indicated that adsorption occurred through a Langmuir process, meaning that it was a monolayer process. This analysis result was in accordance with the results of Figure $7 \mathrm{~b}$.

The effect of the $\mathrm{MB}$ solution $\mathrm{pH}$ on the adsorption capacity was studied, and the results are presented in Figure 8, in which the maximum adsorption capacity was achieved with a strong basic MB solution and the adsorption capacity increased with the solution $\mathrm{pH}$. This result was attributed to the electrostatic interaction between the MB molecules and $\mathrm{MnO}$ nanomixtures. In the previous discussion, the zeta potentials exerted an effect on the adsorption capacity, as MB is a cationic dye. In an acidic solution, the zeta potentials of $\mathrm{MnO}$ nanomixtures were positive, which inhibited $\mathrm{MB}$ adsorption. In contrast, at lower $\mathrm{pH}$ values, the zeta potentials were negative and lower. Therefore, MnO-4 had a high adsorption capacity in a basic MB solution. Meanwhile, the nitrogen doping of $\mathrm{MnO}$ could improve the alkalinity of the solution, which was beneficial for MB adsorption.

The pseudo-first-order and pseudo-second-order kinetic models were used to analyze the kinetics of the adsorption process. The theoretical adsorption capacity of $\mathrm{MnO}-4$ calculated from the pseudo-first-order model was $194 \mathrm{mg} \mathrm{g}^{-1}$, and that calculated from the pseudo-second-order model was $164 \mathrm{mg} \mathrm{g}^{-1}$ (Table 2), which fit well with the experimental data $\left(154 \mathrm{mg} \mathrm{g}^{-1}\right)$. As shown in Figure 9, the $\mathrm{R}^{2}$ values obtained from the pseudo-second-order model were better than the $\mathrm{R}^{2}$ values obtained from the pseudo-first-order model. In conclusion, the pseudo-second-order model was more suitable for investigation of the MB adsorption process. 

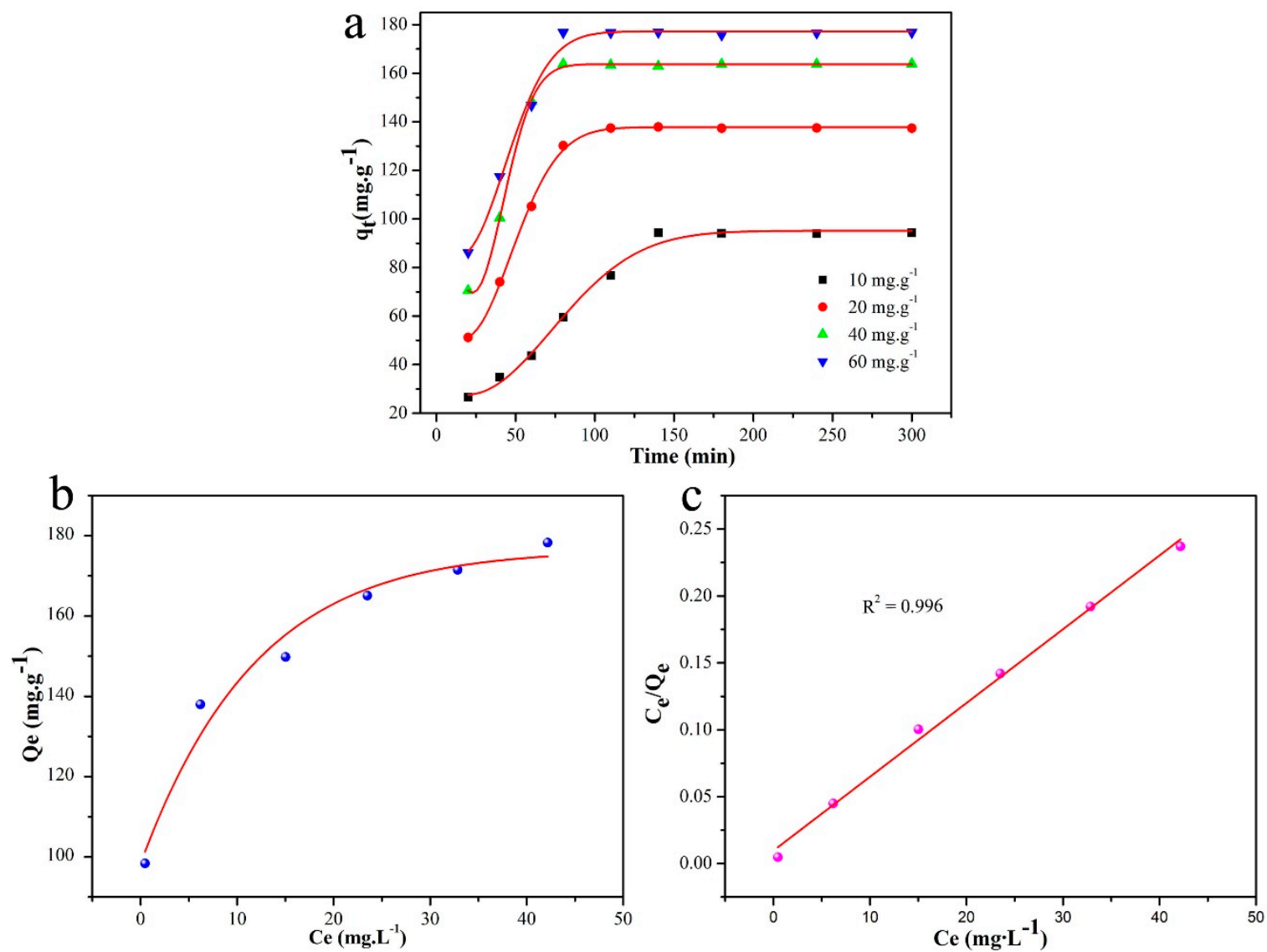

Figure 7. (a) Adsorption curves under different concentrations of MB; (b) adsorption isotherm of an MB solution in MnO-4; (c) Langmuir isotherm plot for MB adsorption in MnO-4.

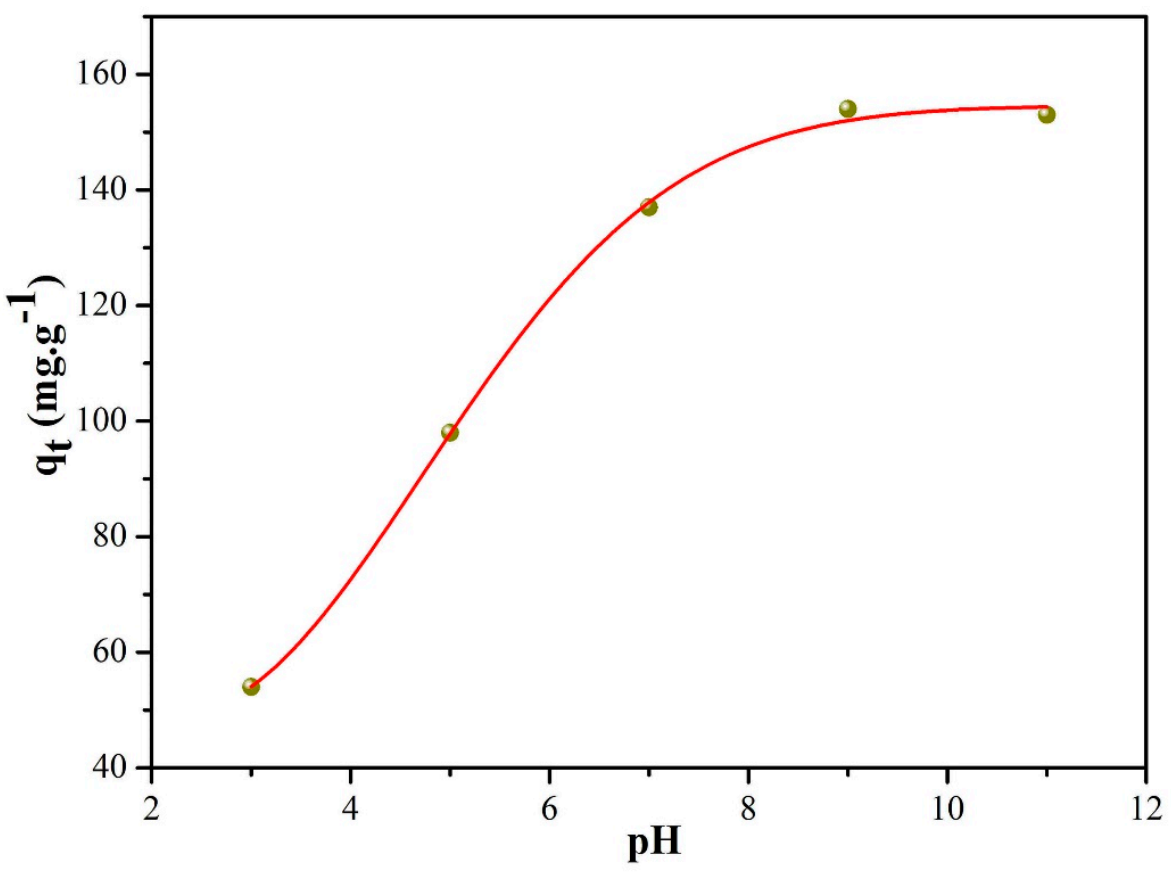

Figure 8. MB adsorption capacity of $\mathrm{MnO}-4$ at different $\mathrm{pH}$ values. 



Figure 9. Pseudo-first-order kinetic model plot (a) and pseudo-second-order kinetic model plot (b).

Table 2. Parameters of pseudo-first-order kinetic model and pseudo-second-order kinetic model for the adsorption of $\mathrm{MB}$ in $\mathrm{MnO}$ nanomixtures.

\begin{tabular}{ccccc}
\hline \multirow{2}{*}{ Entry } & \multicolumn{2}{c}{ Pseudo-First-Order Kinetic Model } & \multicolumn{2}{c}{ Pseudo-Second-Order Kinetic Model } \\
\cline { 2 - 5 } & $\mathbf{K}_{\mathbf{1}}$ & $\mathbf{q}_{\mathbf{e}}\left(\mathbf{m g ~ g}^{-\mathbf{1}}\right)$ & $\mathbf{K}_{\mathbf{2}}$ & $\mathbf{q e}_{\mathbf{e}} \mathbf{m g ~ g}^{\mathbf{- 1}} \mathbf{)}$ \\
\hline $\mathrm{MnO}-2$ & 0.019 & 43.70 & 0.00031 & 150.38 \\
$\mathrm{MnO}-4$ & 0.025 & 194.03 & 0.000097 & 164.12 \\
$\mathrm{MnO}-6$ & 0.021 & 122.85 & 0.00012 & 111.48 \\
$\mathrm{MnO}-24$ & 0.022 & 234.40 & 0.000047 & 160.67 \\
\hline
\end{tabular}

MB adsorption experiments were performed at different temperatures, and the results are shown in Figure 10a. At the same time, the plot of $\ln \mathrm{Kc}$ versus 1/T for MnO-4 is demonstrated in Figure 10b. As presented in Figure 10a, a higher adsorption capacity was obtained at a higher temperature, which indicated that a high temperature was beneficial for $\mathrm{MB}$ adsorption. The $\Delta \mathrm{G}^{0}, \Delta \mathrm{H}^{0}$ and $\Delta \mathrm{S}^{0}$ values of $\mathrm{MB}$ adsorption on MnO-4 were calculated from Equations (6) and (7) [38] to be $-7.4 \mathrm{~kJ} \mathrm{~mol}^{-1}$, $21.5 \mathrm{~kJ} \mathrm{~mol}^{-1}$ and $97.0 \mathrm{~J} \mathrm{~mol}^{-1}$, respectively. The value of $\Delta \mathrm{G}^{0}$ was negative, which demonstrated that spontaneous MB adsorption occurred on the MnO-4 surface. In addition, the value of $\Delta S^{0}$ was positive, which was attributed to an increase in the chaos at the adsorbent/solution interface during $\mathrm{MB}$ adsorption in $\mathrm{MnO}-4$. In addition, the value of $\Delta \mathrm{H}^{0}$ was below $40 \mathrm{~kJ} \mathrm{~mol}{ }^{-1}$, as demonstrated by the physisorption of $\mathrm{MB}$ in $\mathrm{MnO}-4$, and the positive value indicated that the process was endothermic, which was in accordance with the experimental results.


Figure 10. Adsorption curves measured at different temperatures (a) and the plot of $\ln \mathrm{Kc}$ versus $1 / \mathrm{T}$ for MnO-4 (b). 
Repeated experiments were conducted to investigate the reusability of MnO-4 for MB adsorption, and the results are shown in Figure 11. The adsorption capacity was $137 \mathrm{mg} \mathrm{g}^{-1}$ in the first cycle, and $96 \%$ of the adsorption capacity, corresponding to $132 \mathrm{mg} \mathrm{g}^{-1}$, was retained in the last cycle. Therefore, this reusability indicated that MnO-4 was a good adsorbent for MB. Meanwhile, the obtained MnO-4 exhibited excellent adsorption capacity, which could be roughly compared with other reported absorbents shown in Table 3.

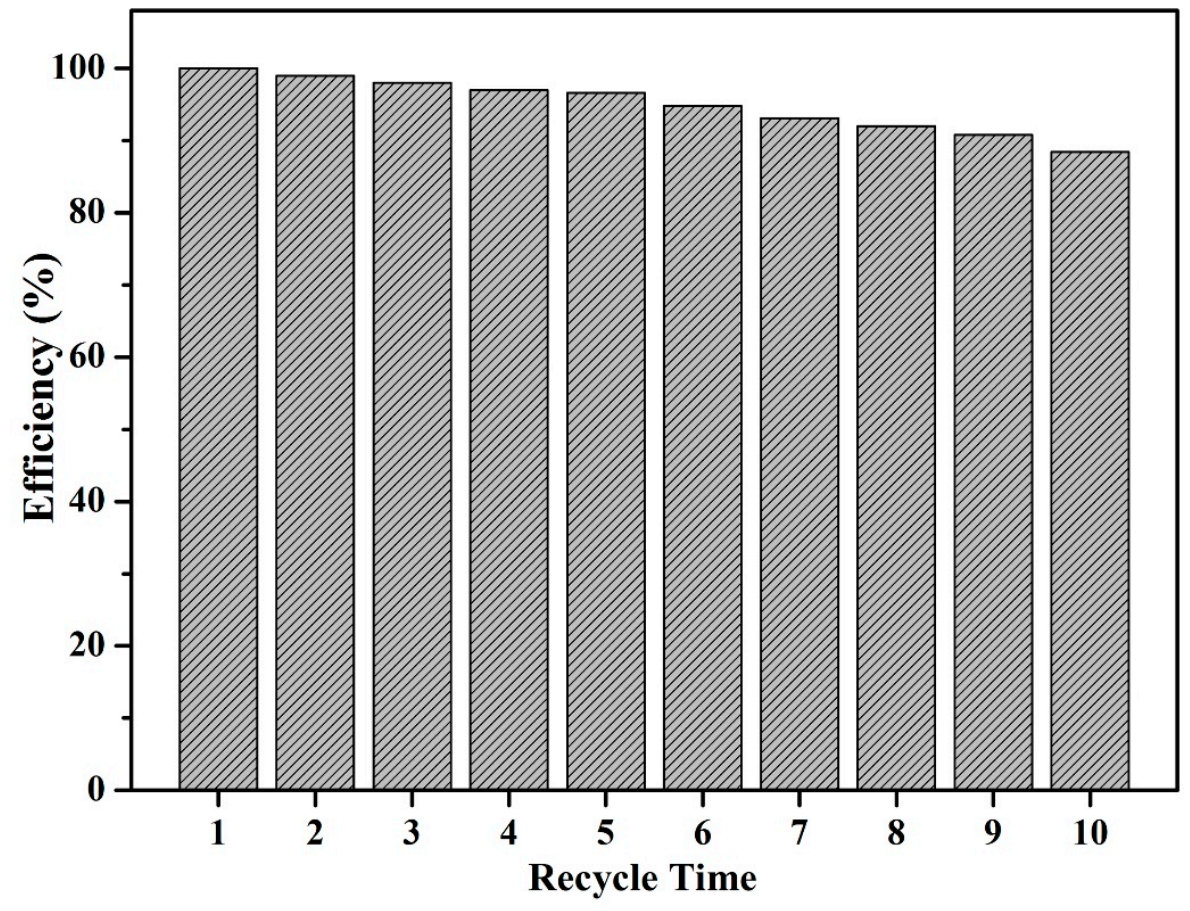

Figure 11. MB adsorption capacities of MnO-4 in 10 adsorption cycles.

Table 3. Comparison of the adsorption capacities of different absorbents from previous reports with that of $\mathrm{C}, \mathrm{N}-\mathrm{MnO}-4$.

\begin{tabular}{ccc}
\hline Adsorbent & $\mathbf{m g ~ g}^{\mathbf{- 1}}$ & Reference \\
\hline Wheat shells & 21.5 & {$[39]$} \\
Chitosan-modified zeolite & 37 & {$[40]$} \\
$\mathrm{Fe}_{3} \mathrm{O}_{4} @ \mathrm{Ag} / \mathrm{SiO}_{2}$ nanospheres & 128.5 & {$[41]$} \\
$\mathrm{N}, \mathrm{Fe}_{2} \mathrm{O}_{3} @$ carboxyl-functionalized yeast composite & 49.5 & {$[42]$} \\
Kaolin & 100.2 & {$[43]$} \\
C, N-doped MnO & 52.7 & {$[44]$} \\
\hline
\end{tabular}

The degradation efficiency of $\mathrm{MB}$ in $\mathrm{MnO}$ nanomixtures was investigated in this work. As shown in Figure 12a, $\mathrm{MnO}$ nanomixtures exhibited high degradation efficiency under different $\mathrm{MB}$ concentrations $\left(99.8 \%, \approx 142 \mathrm{mg} \mathrm{g}^{-1}\right.$ at a MB concentration of $\left.20 \mathrm{mg} \mathrm{L}^{-1}\right)$. As presented in Figure $12 \mathrm{~b}, \mathrm{c}$, the MB solution exhibited a sharp absorption band at $656 \mathrm{~nm}$ in the UV-Vis spectrum, and this absorption band obviously decreased with increasing degradation time. The degradation kinetics were well fitted by the pseudo-first-order model shown in Figure 12d, and the theoretical De (the degradation amount at the degradation equilibrium) value was $146 \mathrm{mg} \mathrm{g}^{-1}$, which was in good agreement with the experimental data. This analysis result indicated that the pseudo-first-order model could effectively describe the MB degradation process in $\mathrm{MnO}$ nanomixtures [45-52]. 

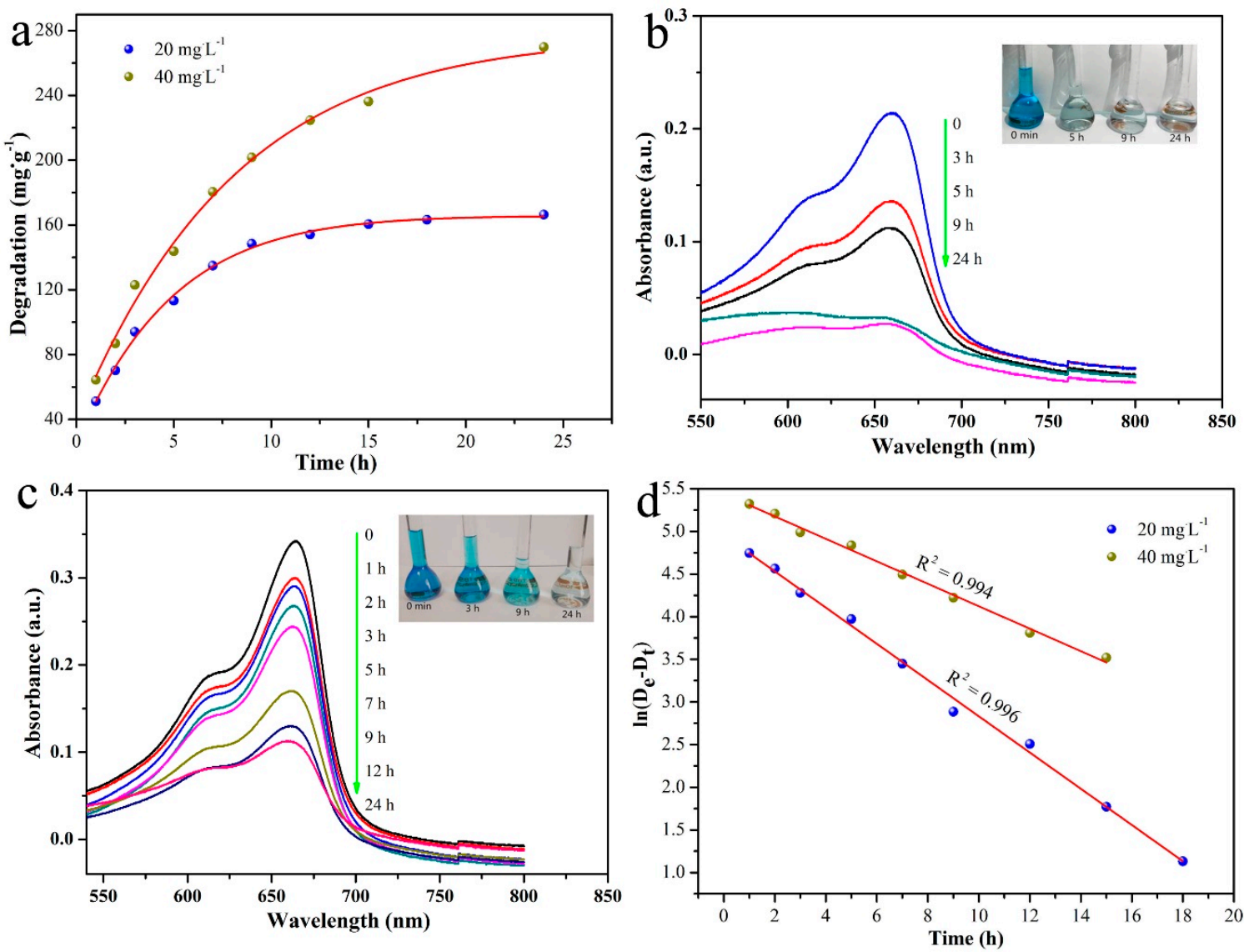

Figure 12. MB degradation curves under different MB concentrations (a); UV-Vis spectra of $20 \mathrm{mg} \mathrm{L}^{-1}$ MB after various degradation times (b); UV-Vis spectra of $40 \mathrm{mg} \mathrm{L}^{-1} \mathrm{MB}$ after various degradation times (c); and pseudo-first-order kinetic model plot of the degradation process (d).

The degradation mechanism of $\mathrm{MB}$ in $\mathrm{MnO}$ nanomixtures was proposed (Figure 13). Active superoxide anions and/or peroxide species could form in the $\mathrm{H}_{2} \mathrm{O}_{2}-\mathrm{MnO}$ system according to previous reports [16,53], and these species could oxidize MB. As shown in Figure 13, $\mathrm{H}_{2} \mathrm{O}_{2}$ was used as an oxidant to form various superoxide anions and peroxide species, and $\mathrm{C} ; \mathrm{N}$-doped $\mathrm{MnO}$ was used as a catalyst to catalyze the decomposition of $\mathrm{H}_{2} \mathrm{O}_{2} . \mathrm{Mn}(\mathrm{III}) / \mathrm{Mn}(\mathrm{II})$ played an important role in the $\mathrm{MB}$ degradation process and contributed to ideal $\mathrm{MB}$ degradation in $\mathrm{C}, \mathrm{N}$-doped $\mathrm{MnO}$. Present obtained $\mathrm{MnO}$ nanomixtures demonstrated potential applications in self-assembled materials design and composites for wide applications [54-65].

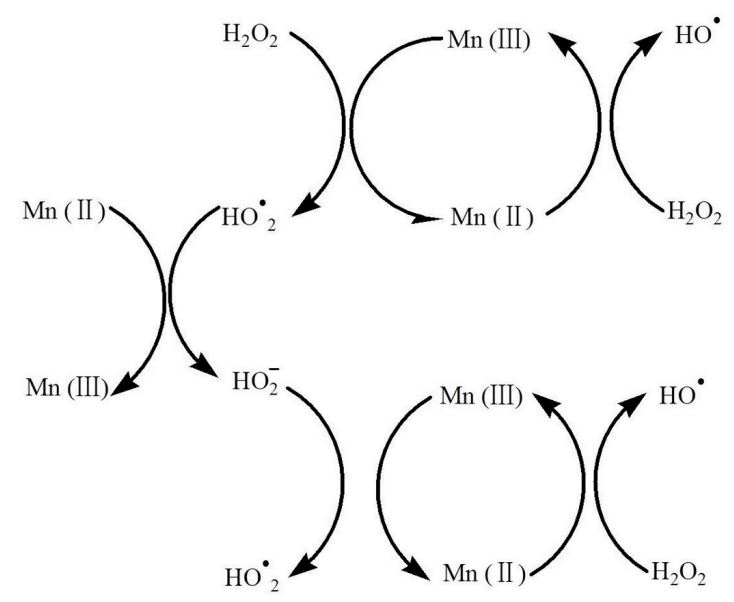

Figure 13. Degradation mechanism of $\mathrm{MB}$ in $\mathrm{MnO}$ nanomixtures. 


\section{Conclusions}

In summary, novel nanoscale rod-shaped $\mathrm{MnO}$ nanomixtures were successfully prepared via a hydrothermal self-assembly method with $\mathrm{C}_{3} \mathrm{~N}_{4}$ as the source of carbon and nitrogen and potassium permanganate $\left(\mathrm{KMnO}_{4}\right)$ as the source of manganese. The as-prepared materials exhibited good $\mathrm{MB}$ adsorption and degradation with $\mathrm{H}_{2} \mathrm{O}_{2}$ as the oxidant. The maximum adsorption capacity was $154 \mathrm{mg} \mathrm{g}^{-1}$, and the optimum degradation efficiency was $99.8 \%$. The adsorption process was very well fitted by the pseudo-second-order model, and the degradation process was very well fitted by the pseudo-first-order model. MB adsorption occurred through physicorption, and MB degradation was caused by a chemical reaction. Meanwhile, $\mathrm{MnO}$ nanomixtures exhibited excellent reusability. The as-prepared $\mathrm{MnO}$ nanomixtures are potential and effective materials for extensive pollutant removal.

Author Contributions: T.J. and Z.L. conceived and designed the experiments; Y.X., B.R., R.W., and L.Z. performed the experiments; T.J. and Y.X. analyzed the data; Y.X. wrote the paper.

Funding: This research was funded by Foundation of Key R\&D Program of Hebei Province (No. 18393616D), science and technology projects of Hebei Academy of Sciences (No. 18707), Natural Science Fund and Key Basic Research Project (No. 18964005D), National Natural Science Foundation of China (Nos. 21872119, 21473153), Support Program for the Top Young Talents of Hebei Province, China Postdoctoral Science Foundation (No. 2015M580214), Research Program of the College Science \& Technology of Hebei Province (No. ZD2018091), and Scientific and Technological Research and Development Program of Qinhuangdao City (No. 201701B004).

Conflicts of Interest: The authors declare no conflict of interest.

\section{References}

1. Marrakchi, F.; Ahmed, M.J.; Khanday, W.A.; Asif, M.; Hameed, B.H. Mesoporous-activated carbon prepared from chitosan flakes via single-step sodium hydroxide activation for the adsorption of methylene blue. Int. J. Biol. Macromol. 2017, 98, 233-239. [CrossRef] [PubMed]

2. Guo, R.; Jiao, T.F.; Li, R.F.; Chen, Y.; Guo, W.C.; Zhang, L.X.; Zhou, J.X.; Zhang, Q.R.; Peng, Q.M. Sandwiched $\mathrm{Fe}_{3} \mathrm{O}_{4}$ /carboxylate graphene oxide nanostructures constructed by layer-by-layer assembly for highly efficient and magnetically recyclable dye removal. ACS Sustain. Chem. Eng. 2018, 6, 1279-1288. [CrossRef]

3. Vaz, M.G.; Pereira, A.G.B.; Fajardo, A.R.; Azevedo, A.C.N.; Rodrigues, F.H.A. Methylene Blue Adsorption on Chitosan-g-Poly(Acrylic Acid)/Rice Husk Ash Superabsorbent Composite: Kinetics, Equilibrium, and Thermodynamics. Water Air Soil Pollut. 2017, 228, 14. [CrossRef]

4. Liu, Y.; Hou, C.; Jiao, T.; Song, J.; Zhang, X.; Xing, R.; Zhou, J.; Zhang, L.; Peng, Q. Self-assembled AgNP-containing nanocomposites constructed by electrospinning as efficient dye photocatalyst materials for wastewater treatment. Nanomaterials 2018, 8, 35. [CrossRef] [PubMed]

5. Ullah, R.; Dutta, J. Photocatalytic degradation of organic dyes with manganese-doped ZnO nanoparticles. J. Hazard. Mater. 2008, 156, 194-200. [CrossRef]

6. Zhao, X.N.; Jiao, T.F.; Ma, X.L.; Huang, H.; Hu, J.; Qu, Y.; Zhou, J.X.; Zhang, L.X.; Peng, Q.M. Facile fabrication of hierarchical diamond-based AuNPs-modified nanomixtures via layer-by-layer assembly with enhanced catalytic capacities. J. Taiwan Inst. Chem. Eng. 2017, 80, 614-623. [CrossRef]

7. Atchudan, R.; Edison, T.N.J.I.; Perumal, S.; Karthik, N.; Karthikeyan, D.; Shanmugam, M.; RokLee, Y. Concurrent synthesis of nitrogen-doped carbon dots for cell imaging and ZnO@nitrogen-doped carbon sheets for photocatalytic degradation of methylene blue. J. Photochem. Photobiol. A Chem. 2018, 350, 75-85. [CrossRef]

8. Tanhaei, M.; Mahjoub, A.R.; Safarifard, V. Sonochemical synthesis of amide-functionalized metal-organic framework/graphene oxide nanocomposite for the adsorption of methylene blue from aqueous solution. Ultrason. Sonochem. 2018, 41, 189-195. [CrossRef]

9. More, A.T.; Vira, A.; Fogel, S. Biodegradation of trans-1, 2-dichloroethylene by methane-utilizing bacteria in an aquifer simulator. Environ. Sci. Technol. 1989, 23, 403-406. [CrossRef]

10. Slokar, Y.M.; Marechal, A.M.L. Methods of decoloration of textile wastewaters. Dyes Pigment. 1998, 37, 335-356. [CrossRef] 
11. Tang, L.; Jia, C.T. Fabrication of compressible and recyclable macroscopic $\mathrm{g}-\mathrm{C}_{3} \mathrm{~N}_{4} / \mathrm{GO}$ aerogel hybrids for visible-light harvesting: A promising strategy for water remediation. Appl. Catal. B Environ. 2017, 219, 241-248. [CrossRef]

12. $\mathrm{Xu}, \mathrm{J} . ;$ Wang, Z.P. Enhanced visible-light-driven photocatalytic disinfection performance and organic pollutant degradation activity of porous g- $\mathrm{C}_{3} \mathrm{~N}_{4}$ nanosheets. ACS Appl. Mater. Interfaces 2017, 9, 27727-27735. [CrossRef]

13. Houas, A.; Lachheb, H.; Ksibi, M.; Elaloui, E.; Guillard, C.; Herrmann, J.M. Photocatalytic degradation pathway of methylene blue in water. Appl. Catal. B Environ. 2001, 31, 145-157. [CrossRef]

14. Cavallaro, G.; Gianguzza, A.; Lazzara, G.; Milioto, S.; Piazzese, D. Alginate gel beads filled with halloysite nanotubes. Appl. Clay Sci. 2013, 72, 132-137. [CrossRef]

15. Cavallaro, G.; Grillo, I.; Gradzielski, M.; Lazzara, G. Structure of Hybrid Materials Based on Halloysite Nanotubes Filled with Anionic Surfactants. J. Phys. Chem. C 2016, 120, 13492-13502. [CrossRef]

16. Li, T.T.; Wang, Z.H.; Liu, C.C.; Tang, C.M.; Wang, X.K.; Ding, G.S.; Ding, Y.C.; Yang, L.X. TiO 2 Nanotubes/Ag/MoS 2 Meshy Photoelectrode with Excellent Photoelectrocatalytic Degradation Activity for Tetracycline Hydrochloride. Nanomaterials 2018, 8, 666. [CrossRef] [PubMed]

17. Riahi-Madvaar, R.; Taher, M.A.; Fazelirad, H. Synthesis and characterization of magnetic halloysite-iron oxide nanocomposite and its application for naphthol green B removal. Appl. Clay Sci. 2017, 137, 101-106. [CrossRef]

18. Minero, C.; Lucchiari, M.; Vione, D.; Maurino, V. Fe(III)-Enhanced Sonochemical Degradation of Methylene Blue In Aqueous Solution. Environ. Sci. Technol. 2005, 39, 8936-8942. [CrossRef]

19. Jiang, F.; Yan, T.T.; Chen, H.; Sun, A.; Xu, C.M.; Wang, X. A g- $\mathrm{C}_{3} \mathrm{~N}_{4}-\mathrm{CdS}$ composite catalyst with high visible-light-driven catalytic activity and photostability for methylene blue degradation. Appl. Surf. Sci. 2014, 295, 164-172. [CrossRef]

20. Xing, S.T.; Zhou, Z.C.; Ma, Z.C.; Wu, Y.S. Characterization and reactivity of $\mathrm{Fe}_{3} \mathrm{O}_{4} / \mathrm{FeMnOx}$ core/shell nanoparticles for methylene blue discoloration with $\mathrm{H}_{2} \mathrm{O}_{2}$. Appl. Catal. B Environ. 2011, 107, 386-392. [CrossRef]

21. Li, Y.Q.; Qu, J.Y.; Gao, F.; Lv, S.Y.; Shi, L.; He, C.X.; Sun, J.C. In situ fabrication of $\mathrm{Mn}_{3} \mathrm{O}_{4}$ decorated graphene oxide as a synergistic catalyst for degradation of methylene blue. Appl. Catal. B Environ. 2015, 162, 268-274. [CrossRef]

22. Randorn, C.; Wongnawa, S.; Boonsin, P. Bleaching of Methylene Blue by Hydrated Titanium Dioxide. Sci. Asia 2004, 30, 149-156. [CrossRef]

23. Wang, Z.H.; Zhao, H.Q.; Qi, H.B.; Liu, X.Y.; Liu, Y. Free radical behaviours during methylene blue degradation in the $\mathrm{Fe}^{2+} / \mathrm{H}_{2} \mathrm{O}_{2}$ system. Environ. Technol. 2017. [CrossRef] [PubMed]

24. Bhattacharyya, G.K.; Sharma, A. Kinetics and thermodynamics of Methylene Blue adsorption on Neem (Azadirachta indica) leaf powder. Dyes Pigment. 2005, 65, 51-59. [CrossRef]

25. de Brito Benetoli, L.O.; Cadorin, B.M.; Baldissarelli, V.Z.; Geremias, R.; de Souza, I.G.; Debacher, N.A. Pyrite-enhanced methylene blue degradation in non-thermal plasma water treatment reactor. J. Hazard. Mater. 2012, 237, 55-62. [CrossRef] [PubMed]

26. Wang, H.; Huang, Y.M. Prussian-blue-modified iron oxide magnetic nanoparticles as effective peroxidase-like catalysts to degrade methylene blue with $\mathrm{H}_{2} \mathrm{O}_{2}$. J. Hazard. Mater. 2011, 191, 163-169. [CrossRef] [PubMed]

27. Wolski, L.; Ziolek, M. Insight into pathways of methylene blue degradation with $\mathrm{H}_{2} \mathrm{O}_{2}$ over mono and bimetallic Nb, Zn oxides. Appl. Catal. B Environ. 2018, 224, 634-647. [CrossRef]

28. Prathap, M.U.A.; Kaur, B.; Srivastava, R. Hydrothermal synthesis of CuO micro-/nanostructures and their applications in the oxidative degradation of methylene blue and non-enzymatic sensing of glucose $/ \mathrm{H}_{2} \mathrm{O}_{2}$. J. Colloid Interface Sci. 2012, 370, 144-154. [CrossRef]

29. Saha, M.; Gayen, A.; Mukherjee, S. Microstructure, morphology, and methylene blue degradation over nano- $\mathrm{CuFe}_{2} \mathrm{O}_{4}$ synthesized by a modified complexometric method. J. Aust. Ceram. Soc. 2018, 54, 513-522. [CrossRef]

30. Zhang, P.Q.; Zhan, Y.G.; Cai, B.X.; Hao, C.C.; Wang, J.; Liu, C.X.; Meng, Z.J.; Yin, Z.L.; Chen, Q.Y. Shape-Controlled Synthesis of $\mathrm{Mn}_{3} \mathrm{O}_{4}$ Nanocrystals and Their Catalysis of the Degradation of Methylene Blue. Nano Res. 2010, 3, 235-243. [CrossRef]

31. Cai, X.G.; He, J.Y. A $2 \mathrm{D}-\mathrm{g}-\mathrm{C}_{3} \mathrm{~N}_{4}$ nanosheet as an eco-friendly adsorbent for various environmental pollutants in water. Chemosphere 2017, 171, 192-201. [CrossRef] [PubMed] 
32. Xin, G.; Meng, Y.L. Pyrolysis Synthesized g- $\mathrm{C}_{3} \mathrm{~N}_{4}$ for Photocatalytic Degradation of Methylene Blue. J. Chem. 2013, 2013, 187912. [CrossRef]

33. Li, K.Y.; Fang, Z.L.; Xiong, S.; Luo, J. Novel graphitic- $\mathrm{C}_{3} \mathrm{~N}_{4}$ nanosheets: Enhanced visible light photocatalytic activity and photoelectrochemical detection of methylene blue dye. Mater. Technol. 2017, 32, 391-398. [CrossRef]

34. Chang, F.; Xie, Y.C.; Li, C.L.; Chen, J.; Luo, J.R.; Hu, X.F.; Shen, J.W. A facile modification of g-C ${ }_{3} \mathrm{~N}_{4}$ with enhanced photocatalytic activity for degradation of methylene blue. Appl. Surf. Sci. 2013, 280,967-974. [CrossRef]

35. Mao, Y.; Wu, M.Z.; Li, G.; Dai, P.; Yu, X.X.; Bai, Z.M.; Chen, P. Photocatalytic degradation of methylene blue over boron-doped $g-\mathrm{C}_{3} \mathrm{~N}_{4}$ together with nitrogenvacancies under visible light irradiation. React. Kinet. Mech. Catal. 2018, 125, 1179-1190. [CrossRef]

36. Chu, Y.T.; Guo, L.Y.; Xi, B.J.; Feng, Z.Y.; Wu, F.F.; Lin, Y.; Liu, J.C.; Sun, D.; Feng, J.K.; Qian, Y.T.; et al. Embedding $\mathrm{MnO} @ \mathrm{Mn}_{3} \mathrm{O}_{4}$ Nanoparticles in an N-Doped-Carbon Framework Derived from Mn-Organic Clusters for Effcient Lithium Storage. Adv. Mater. 2018, 30, 1704244. [CrossRef] [PubMed]

37. Dong, G.H.; Zhao, K. Carbon self-doping induced high electronic conductivity and photoreactivity of g- $\mathrm{C}_{3} \mathrm{~N}_{4}$. Chem. Commun. 2012, 48, 6178-6180. [CrossRef] [PubMed]

38. Ren, B.; Xu, Y.L.; Zhang, L.H.; Liu, Z.F. Carbon-doped graphitic carbon nitride as environment-benign adsorbent for methylene blue adsorption: Kinetics, isotherm and thermodynamics study. J. Taiwan Inst. Chem. Eng. 2018, 88, 114-120. [CrossRef]

39. Bulut, Y.; Aydın, H. A kinetics and thermodynamics study of methylene blue adsorption on wheat shells. Desalination 2006, 194, 259-267. [CrossRef]

40. Xie, J.; Li, C.J. Chitosan modified zeolite as a versatile adsorbent for the removal of different pollutants from water. Fuel 2013, 103, 480-485. [CrossRef]

41. Saini, J.; Garg, V.K.; Gupta, R.K. Removal of Methylene Blue from aqueous solution by $\mathrm{Fe}_{3} \mathrm{O}_{4} @ \mathrm{Ag} / \mathrm{SiO} 2$ nanospheres: Synthesis, characterization and adsorption performance. J. Mol. Liq. 2018, 250, 413-422. [CrossRef]

42. Wang, Y.; Zhang, W.; Qin, M.; Zhao, M.J.; Zhang, Y.S. Green one-pot preparation of $\alpha-\mathrm{Fe}_{2} \mathrm{O}_{3} @$ carboxylfunctionalized yeast composite with high adsorption and catalysis properties for removal of methylene blue. Surf. Interface Anal. 2017, 50, 311-320. [CrossRef]

43. Chen, B.L.; Yang, Z.X.; Ma, G.P.; Kong, D.L.; Xiong, W.; Wang, J.B.; Zhu, Y.Q.; Xia, Y.D. Heteroatom-doped porous carbons with enhanced carbon dioxide uptake and excellent methylene blue adsorption capacities. Microporous Mesoporous Mater. 2018, 257, 1-8. [CrossRef]

44. Mounia, L.; Belkhir, L.I.; Bollinger, J.C.; Bouzaza, A.; Assadi, A.; Tirri, A.; Dahmoune, F.; Madani, K.; Remini, H. Removal of Methylene Blue from aqueous solutions by adsorption on Kaolin: Kinetic and equilibrium studies. Appl. Clay Sci. 2018, 153, 38-45. [CrossRef]

45. Xing, R.; Wang, W.; Jiao, T.; Ma, K.; Zhang, Q.; Hong, W.; Qiu, H.; Zhou, J.; Zhang, L.; Peng, Q. Bioinspired polydopamine sheathed nanofibers containing carboxylate graphene oxide nanosheet for high-efficient dyes scavenger. ACS Sustain. Chem. Eng. 2017, 5, 4948-4956. [CrossRef]

46. Zhao, X.; Ma, K.; Jiao, T.; Xing, R.; Ma, X.; Hu, J.; Huang, H.; Zhang, L.; Yan, X. Fabrication of hierarchical layer-by-layer assembled diamond based core-shell nanocomposites as highly efficient dye absorbents for wastewater treatment. Sci. Rep. 2017, 7, 44076. [CrossRef] [PubMed]

47. Guo, H.; Jiao, T.; Zhang, Q.; Guo, W.; Peng, Q.; Yan, X. Preparation of graphene oxide-based hydrogels as efficient dye adsorbents for wastewater treatment. Nanoscale Res. Lett. 2015, 10, 272. [CrossRef] [PubMed]

48. Li, K.; Jiao, T.; Xing, R.; Zou, G.; Zhou, J.; Zhang, L.; Peng, Q. Fabrication of tunable hierarchical MXene@AuNPs nanocomposites constructed by self-reduction reactions with enhanced catalytic performances. Sci. China Mater. 2018, 61, 728-736. [CrossRef]

49. Wang, C.; Sun, S.; Zhang, L.; Yin, J.; Jiao, T.; Zhang, L.; Xu, Y.; Zhou, J.; Peng, Q. Facile preparation and catalytic performance characterization of AuNPs-loaded hierarchical electrospun composite fibers by solvent vapor annealing treatment. Colloid Surf. A Physicochem. Eng. Asp. 2019, 561, 283-291. [CrossRef]

50. Chen, K.; Li, J.; Zhang, L.; Xing, R.; Jiao, T.; Gao, F.; Peng, Q. Facile synthesis of self-assembled carbon nanotubes/dye composite films for sensitive electrochemical determination of Cd(II) ions. Nanotechnology 2018, 29, 445603. [CrossRef] 
51. Huang, X.; Jiao, T.; Liu, Q.; Zhang, L.; Zhou, J.; Li, B.; Peng, Q. Hierarchical electrospun nanofibers treated by solvent vapor annealing as air filtration mat for high-efficiency PM2.5 capture. Sci. China Mater. 2018. [CrossRef]

52. Li, N.; Tang, S.; Rao, Y.; Qi, J.; Wang, P.; Jiang, Y.; Huang, H.; Gu, J.; Yuan, D. Improved dye removal and simultaneous electricity production in a photocatalytic fuel cell coupling with persulfate. Electrochim. Acta 2018, 270, 330-338. [CrossRef]

53. Jiang, J.Z.; Zou, J.; Zhu, L.H.; Huang, L.; Jiang, H.P.; Zhang, Y.X. Degradation of Methylene Blue with $\mathrm{H}_{2} \mathrm{O}_{2}$ Activated by Peroxidase-Like $\mathrm{Fe}_{3} \mathrm{O}_{4}$ Magnetic Nanoparticles. J. Nanosci. Nanotechnol. 2011, 11, 4793-4799. [CrossRef] [PubMed]

54. Zhou, J.; Gao, F.; Jiao, T.; Xing, R.; Zhang, L.; Zhang, Q.; Peng, Q. Selective Cu(II) ion removal from wastewater via surface charged self-assembled polystyrene-Schiff base nanocomposites. Colloid Surf. A Physicochem. Eng. Asp. 2018, 545, 60-67. [CrossRef]

55. Tang, S.; Li, X.; Zhang, C.; Liu, Y.; Zhang, W.; Yuan, D. Strengthening decomposition of oxytetracycline in DBD plasma coupling with Fe-Mn oxides loaded granular activated carbon. Plasma Sci. Technol. 2018. [CrossRef]

56. Luo, X.; Ma, K.; Jiao, T.; Xing, R.; Zhang, L.; Zhou, J.; Li, B. Graphene oxide-polymer composite Langmuir films constructed by interfacial thiol-ene photopolymerization. Nanoscale Res. Lett. 2017, 12, 99. [CrossRef] [PubMed]

57. Huo, S.; Duan, P.; Jiao, T.; Peng, Q.; Liu, M. Self-assembled luminescent quantum dots to generate full-color and white circularly polarized light. Angew. Chem. Int. Ed. 2017, 56, 12174-12178. [CrossRef]

58. Song, J.; Xing, R.; Jiao, T.; Peng, Q.; Yuan, C.; Möhwald, H.; Yan, X. Crystalline dipeptide nanobelts based on solid-solid phase transformation self-assembly and their polarization imaging of cells. ACS Appl. Mater. Interfaces 2018, 10, 2368-2376. [CrossRef]

59. Zhang, R.Y.; Xing, R.R.; Jiao, T.F.; Ma, K.; Chen, C.J.; Ma, G.H.; Yan, X.H. Synergistic in vivo photodynamic and photothermal antitumor therapy based on collagen-gold hybrid hydrogels with inclusion of photosensitive drugs Colloids and Surfaces A: Physicochemical and Engineering Aspects. ACS Appl. Mater. Interfaces 2016, 8, 13262-13269. [CrossRef]

60. Xing, R.; Jiao, T.; Liu, Y.; Ma, K.; Zou, Q.; Ma, G.; Yan, X. Co-assembly of graphene oxide and albumin/photosensitizer nanohybrids towards enhanced photodynamic therapy. Polymers 2016, 8, 181. [CrossRef]

61. Xing, R.; Liu, K.; Jiao, T.; Zhang, N.; Ma, K.; Zhang, R.; Zou, Q.; Ma, G.; Yan, X. An injectable self-assembling collagen-gold hybrid hydrogel for combinatorial antitumor photothermal/photodynamic therapy. Adv. Mater. 2016, 28, 3669-3676. [CrossRef]

62. Zhou, J.; Liu, Y.; Jiao, T.; Xing, R.; Yang, Z.; Fan, J.; Liu, J.; Li, B.; Peng, Q. Preparation and enhanced structural integrity of electrospun poly( $\varepsilon$-caprolactone)-based fibers by freezing amorphous chains through thiol-ene click reaction. Colloid Surf. A Physicochem. Eng. Asp. 2018, 538, 7-13. [CrossRef]

63. Liu, K.; Yuan, C.Q.; Zou, Q.L.; Xie, Z.C.; Yan, X.H. Self-assembled Zinc/cystine-based chloroplast mimics capable of photoenzymatic reactions for sustainable fuel synthesis. Angew. Chem. Int. Ed. 2017, 56, 7876-7880. [CrossRef] [PubMed]

64. Liu, K.; Xing, R.R.; Li, Y.X.; Zou, Q.L.; Möhwald, H.; Yan, X.H. Mimicking primitive photobacteria: Sustainable hydrogen evolution based on peptide-porphyrin co-assemblies with self-mineralized reaction center. Angew. Chem. Int. Ed. 2016, 55, 12503-12507. [CrossRef] [PubMed]

65. Liu, K.; Xing, R.R.; Chen, C.J.; Shen, G.Z.; Yan, L.Y.; Zou, Q.L.; Ma, G.H.; Möhwald, H.; Yan, X.H. Peptide-induced hierarchical long-range order and photocatalytic activity of porphyrin assemblies. Angew. Chem. Int. Ed. 2015, 54, 500-505. [CrossRef]

(C) 2018 by the authors. Licensee MDPI, Basel, Switzerland. This article is an open access article distributed under the terms and conditions of the Creative Commons Attribution (CC BY) license (http:/ / creativecommons.org/licenses/by/4.0/). 